\title{
The Symbol of the Phoenix in the Catacombs of Priscilla in Rome and Its Transformation in Early Christianity
}

\author{
Mária Kardis \\ University of Prešov \\ maria.kardis@unipo.sk \\ https://orcid.org/0000-0003-1775-2615 \\ Dominika Tlučková \\ University of Prešov \\ dominika.tluckova@smail.unipo.sk \\ (10) https://orcid.org/0000-0001-8557-4713
}

\begin{abstract}
The presented study deals with the oldest Christian depiction of a phoenix found in the Catacombs of Priscilla in Rome. Since catacomb art is a narrative depiction of biblical stories, it is important to incorporate the motive of phoenix into historical context. The study performs analysis and comparison the links and connections of the phoenix symbol in pagan and Christian thought. As Christian iconography is associated with allegorical symbols, the intention is to anticipate the meaning, origin and etymology of the phoenix symbol. The article therefore summarizes how the symbol and position of the phoenix found in the catacombs evolved from Egyptian myths through Greek and Roman culture to the transformation in Christian literature and Christian thought, especially in the Gospel of John, which connects the symbol of the phoenix with the palm and Lazarus.
\end{abstract}

KEYwORDs: phoenix symbolism, catacombs of Priscilla, mythology, Early Christianity art

Introducing the issue, it is necessary to keep in mind that the space in the catacombs was shared by pagans, Jews and Christians. They could have been Jews or pagans who, on the contrary, later became Christians. Both artistic and literary sources provide us with two different interpretations, which refer to their "authors" as well as to the addressees. On one hand, there are Christians who longed to understand the signs that carried the Christian faith. On the other hand, the Romans, who perceived it as traditional art, objects and art forms, that defined their identity and culture. In the catacombs we can find images of Greek-Roman gods, plants, animals and a lot more. The value and specifics of these symbols go back a long way. The Christians of the $1^{\text {st }}$ century, living in Rome in the company of pagans, were hated, persecuted and murdered after the accusations of Emperor Nero. The religion of Christians was considered illegal, and in a sense, considered a Jewish sect, even a dangerous superstition. Christianity represented something new because it was based on the eschatological mission of the resurrected Messiah filling the time of preparation for repentance between glorification and parousia. Because of its distinctive Christology and soteriology, 
it had to come into controversy with Palestinian Judaism as well as Hellenism. Christianity is the new movementof the history of religion, based on the eschatological universalism of the Old Testament prophets; it had no parallel in the ancient world. However, the establishment of Christianity was preceded by a complicated process of separation from the synagogue, which was marked by fierce polemics on the part of Judaism (both Temple and nascent rabbinic). It was a process of forming one's own religious identity, accompanied by the persecution and martyrdom of Jesus himself and his followers (disciples). ${ }^{1}$

As Christians could not openly profess their faith, they used symbols as evidenced by the images on the walls of the catacombs and even often tombstones with epitaphs ${ }^{2}$ that sealed the tomb. The walls of the Christian catacombs are decorated with motives painted using the fresco method, which they got their name after. Among other things, these frescoes represent biblical scenes from the New and Old Testaments, which carry a certain symbolic meaning. Christians used symbols as a visible reminder of their faith in the idea. ${ }^{3}$ They express a summary of the Christian faith as experienced by Christians ${ }^{4}$ at the time.

\section{Phoenix in Early Christian Art}

In the study, we focus on the analysis of the symbol of phoenix in early Christian art. The phoenix appears in various frescoes, mosaics and paintings as early as the beginning of the $2^{\text {nd }}$ century. His depiction in Christian art was under the auspices of the teachers of the faith, as a symbol of their teaching and as an image of Christ. All his depictions were in accordance with the ideas of rebirth, resurrection or rediscovery, victory and martyrdom. Perhaps, the most important legacy of the phoenix in Christian art is his reference to the image of Christ rising from the dead and triumphing over death. In some images, the phoenix appears on a palm tree. According to Martigny, the phoenix is depicted on

1 Based on the available Christian sources, the relationship between the Synagogue and the Church has been marked by polemics and apologetics from the beginning. The origins of the relationship are complicated by the fact that Synagogue and Church, Judaism and Christianity are not homogeneous entities from their inception, and this pluralism has had an impact on the nature of the relationship. M.S. Wróbel, "Motywy i formy żydowskich prześladowań pierwotnego Kościoła (I-II w. po Chr.), BibAn 3 (2013) 421-423. See more: M. Rosik, "Zarzewie konfliktu między Kościołem a Synagogą (do 135 roku)," Jezus i chrześcijanie w źródtach rabinicznych (eds. K. Pilarczyk - A. Mrozek) (Estetyka i Krytyka 27; Kraków: Antykwa 2012) 69-103; S.T. Katz, "The Rabbinic Response to Christianity," The Cambridge History of Judaism. The Late Roman-Rabbinic Period (ed. S.T. Katz) (Cambridge: Cambridge University Press 2006) IV, 259-297; J.T. Sanders, Schismatics, Sectarians, Dissidents, Deviants. The First One Hundred Years of Jewish-Christian Relations (Valley Forge, PA: Trinity Press International 1993).

2 Marble tombstones with epitaphs engraved with the name and period in which the survivor lived (for example, Livia Primitiva, lived for 24 years and 9 days), depicted together with a fish, anchor or dove (we can also also find the Good Shepherd, dolphin or even depictions objects as a symbol of the profession (e.g. pliers when he was a medic or dentist, a boat - when he was a fisherman, etc.).

3 Istituto Salesiano San Callisto, "The Symbols," The Christian Catacombs of Rome. The Catacombs of Saint Callixtus, https://www.catacombe.roma.it/en/simboli-cristiani.php [access: 15.07.2020].

4 Istituto Salesiano San Callisto, "The symbols." 
a palm tree behind the apostle Paul, ${ }^{5}$ because Paul was an ardent preacher of the doctrine of Christ's resurrection. ${ }^{6}$

In early Christian art, the phoenix is depicted on a mosaic in the dome of the Church of S. Giovanni in Ponte in Naples (around the $4^{\text {th }}$ century), on a sarcophagus in the Vatican museums ${ }^{7}$ (Pio Cristiano, inv. 150A, the end of the $4^{\text {th }}$ century). In pictorial form, the palm tree is associated with a phoenix on a mosaic in the Basilica of St. Cosmas and Damian (526-530 AD)..$^{8}$ In mosaics dating from about the $4^{\text {th }}$ century. The phoenix still appears in a villa in Piazza Armerina - Sicily and near Aquileia. ${ }^{9}$

\section{Phoenix in the Catacombs of Priscilla ${ }^{10}$}

The phoenix in Christian iconography first appears on the walls of the catacombs of St. Priscilla in Rome. A catacomb painting appears on the wall of the Cappella Greca chapel, which dates to the end of the $2^{\text {nd }}$ century, but currently its dating is shifted about a century later. ${ }^{11}$

The Catacombs of Priscilla are located on the Via Salaria in Rome, and the first two levels ( 3 to 8 metres below the surface) of the catacombs were probably named after the Priscilla of Acili. Priscilla belonged to a senatorial family, whose name appears on one of the inscriptions in the Acili hypogeum. ${ }^{12}$ These catacombs differ from other catacombs ${ }^{13}$ in their origin, as they grew into an arenarium. ${ }^{14}$ Christians did not begin to use these catacomb

5 Mosaic in the Basilica of St. Cosmos and Damian.

6 L. Charbonneau-Lassay, The Bestiary of Christ (New York: Parabola Books 1991) 447-449.

7 For example. Passion sarcophagus, which depicts a military trophy to the symbol of the resurrection in the central emblem.

8 Cf. J. Royt - H. Šedinová, Slovnik symboliu. Kosmos, príroda a člověk v křestanské ikonografii (Praha: Mladá Fronta 1998) 176.

$9 \quad$ See: F.E. Romer, “Another Incarnation of the Phoenix," Classica et Mediaevalia 54 (2003) 237.

10 For more information on what these catacombs really look like, we offer a link where you can move around virtually to take a tour of the Catacombs of Priscilla: https://www.google.com/maps/place/Catacombs+of+Priscilla/@41.9293271,12.5090897,2a,75y,108.66h,116.7t/data=!3m6!1e1!3m4!1sYe7NvV1aflAAAAQJOCI aFQ!2e0!7i13312!8i6656!4m5!3m4!1s0x132f614730819a3f:0x6ac5a8c1e54625b!8m2!3d41.9296856! $4 \mathrm{~d} 12.5086347$ [access: 12.05.2020].

We also recommend you to look at the fresco of the phoenix (this particular link will take you directly to the Greek Chapel and is directed to the fresco of the phoenix) in the Greek Chapel, as well as other frescoes of early Christian art that adorn the walls of the catacombs and which have been preserved.

11 See Romer, "Another Incarnation of the Phoenix," 237.

12 Hypogeum - an ancient underground burial room.

13 For more information on the origin of the catacombs and catacomb art, see: M. Kardis - D. Tlučková, "Historicko-religionistická analýza typológií pohanských symbolov v krestanských katakombách v Ríme [Historical-Religious Studies of Typologies of Pagan Symbols in Christian Catacombs in Rome]," Historia Ecclesiastica 10/2 (2019) 14-38, https://www.unipo.sk/public/media/34840/historia_ecclesiastica_02_2019_WEB.pdf [access: 27.8.2020].

14 Arenarium - sandpit or quarries from pozzolan (fine-grained tuff). See image: https://www.istockphoto. com/vector/secret-stairway-to-arenarium-gm1045929180-279878024 [access: 15.03.2021]. 
galleries ${ }^{15}$ until the early $3^{\text {rd }}$ century, where they built and created about 20 tombs and niches and dug hundreds of loculus ${ }^{16}$ (graves) into the gallery walls. These loculi were bricked with a burial plate (tombstone) to prevent, among other things, the walls from falling. At this first level are logically the oldest graves, including the hypogea of the Acili family (Acili Glabriones) and the so-called Greek chapel. The Greek chapel is heading towards the so-called Cryptoporticus. ${ }^{17}$ On the niche at the top is a fresco of three magicians ${ }^{18}-\mathrm{Ad}-$ oration of Magi (Matt 2), a symbol of the founding of the church. At the same time, this picture is one of the oldest frescoes depicting the Virgin Mary with a child. Right opposite, on the entrance wall, on the right, is a fresco of three bachelors in a burning furnace (Dan 3:15-24.43-50) as a symbol of faith. Above is a fresco of Moses, which brings water from the stone using a stick (Exod 17:6) as a symbol and archetype of baptism. Furthermore, there are frescoes as the healing of the paralyzed, which is a symbol of repentance (Matt 9:2, Mark 2:2-6, Luke 5:18-20). The following is the story of Zuzana (Dan 13), which symbolizes faith in God in times of persecution and suffering. There is also a fresco of the funeral ${ }^{19}$ feast,${ }^{20}$ which is located in the center of the second niche in the back of the chapel. Joseph Wilpert theorized that the Greek Chapel was a church cemetery based on the depicted euchrastic interpretation of the banquet/funeral scene (fractiopanis breaking of bread). After examining Wilpert Joseph's theory, the researchers believed that the room was also used for funerals, based on some graves and a brick seating bench. As for the chapel in the chronology of the paintings, scientists currently date them back to the period of Emperor Gallienus ${ }^{21}$ (253-268 AD).

15 Galleries - it is a name for underground corridors, walls (arcosolia, hypogea, loculi, cubiculum). These corridors (galleries) could have been several meters long, had flat or vaulted ceilings. They were usually $1 \mathrm{~m}$ wide and about $2-3 \mathrm{~m}$ high. (Author's note).

16 Loculus/sepolcro and fossa - horizontal, oblong niche in the wall, rectangular in shape. Usually the loculi were placed on top of each other and arranged in vertical rows (it depended on the height of the gallery walls), mostly the loculi were used to bury one person, but there were also cases where two bodies were buried. See image: https://www.gettyimages.com.mx/detail/ilustración/loculi-open-and-closed-ilustraciones-libres-de-derechos/1045929420 [access: 08.06.2020].

17 The decorations from the $2^{\text {nd }}$ century consist of ornaments and biblical frescoes that cover the vaulted ceiling and the top of the walls. Stucco panels with marble imitation are drawn and shaped below.

18 Mages are depicted as three characters, each with a different color (diversity).

19 This fresco depicts seven figures sitting at a table, including a veiled woman. On the far left is a bearded person wearing a tunic and a pallium, stretching out his arms to break bread. On the table in front of them are goblets of wine, a plate with two fish and one with five loaves of bread. The location of the fresco is bounded by seven baskets of bread, three of which are on one side and four are on the other. See: F. Mancinelli U.M. Fasola, Guide to the Catacombs of Rome (Trevi: Scala - Tecnostampa 2015) 51-52. To preview the fresco or other frescoes from the catacombs: https://www.google.com/maps/place/Catacombs+of+Priscilla/@ 41.9293392,12.5090929,2a,60y,1.85h,113.27t/data=!3m6!1e1!3m4!1sSTeIW_-IUbkAAAQJOCHyIg!2e0!7i13312!8i6656!4m5!3m4!1s0x132f614730819a3f:0x6ac5a8c1e54625b!8m2!3d41.9296221! 4d12.5085324 [access: 12.05.2020].

20 Mancinelli - Fasola, Guide to the Catacombs of Rome, 52.

21 R. Giuliani - B. Mazzei, The Catacombs of Priscilla (Vatican City: Pontifical Commission of Sacred Archaeology 2016) 39 . 
Next to the entrance hall on the right side of the wall is a phoenix pictured dying in flames (Figure 1). According to oriental myths, which were also accepted by the local culture, this fairy-tale bird lived a long time, then perished in burning flames and then was finally reborn from the ashes. Therefore, it became a symbol of eternity and a symbol of new birth, renewal ${ }^{22}$. The Christian community, its art and literature have taken over the myth of the phoenix to express the mystery of the renewal of the body, virginity and purity - which is why the phoenix is depicted in frescoes with the story of Zuzana. However, the depiction of the phoenix style in the Catacombs of Priscilla is really rare, as the phoenix is on fire, his chest and head are surrounded by a halo, pink light and blue rays (Figure 2). The phoenix therefore looks like a point of self-immolation. In 1951, this fresco of the phoenix was restored by the Benedictine Annunziata Maruffi (Figure 3).23

\section{Phoinix vs. Phoenix (Palm vs. Phoenix)}

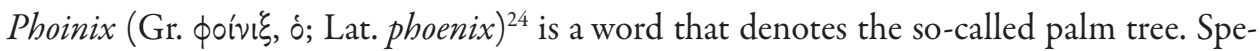

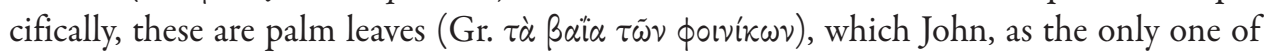
the four evangelists, specifies when describing Jesus' entry into Jerusalem, in which they are placed before Jesus on the path (compare Luke 19:28-40; Matt 21:1-17; Mark 11:1-11; John 12:1-19) more identical than John, who is the only one who specifically mentions palm leaves, the branches of the leaf. Specifically the palm leaf is actually a multi-meaning word that clearly designates the palm tree and the mythical bird. Frank E. Romer in his study Another incarnation of The Phoenix analyzes and explains that John's specification of the branches refined to palm leaves (Hebr. lulavim) is not accidental, just as there is no accidental passage of the resurrected Lazarus ${ }^{25}$ before Jesus entered Jerusalem (John 12:1-11). He explains that this is an important motive in fragments (stories) that refer to immortality

$22 \pi \alpha \lambda เ \gamma \gamma \varepsilon v \varepsilon \sigma i \alpha$ - the future as the restoration and renewal of the world new age (Matt 19:28); as spiritual and moral renewal of an individual new birth, regeneration (Titus 3:5). See: T. Friberg - B. Friberg - N.F. Miller Analytical Lexicon of the Greek New Testament (BibleWorks 10).

23 Giuliani - Mazzei, The Catacombs of Priscilla, 42-43.

24 designations of the word - palm tree, date palm John 12:13; palm branches, palm leaves Rev 7:9; Phoenician. Frank E. Romer explains the denotative meaning of the words Phoenician, Phoenicians and Phoenician red. It was a dye that was produced along the Levantine coast. The production of this paint was very expensive, which meant that the paint was associated only with the rich, powerful and strong people. Phoenician red is a color that is purple, magenta, also known as Tyrian purple. Another connotation of the meaning of the word phoenician red is that Pliny the Elder in his book Naturalis historia X. In the $10^{\text {th }}$ book and the $3^{\text {rd }}$ paragraph he writes about the species of birds. Among other things, he also mentions a phoenix, whose color is purple (purpureus). A closer description of the phoenix by Pliny the Elder is given in the paragraph on phoenix, or depending on the fact that the word phoenix meant unique in Arabic. In: Friberg - Friberg - Miller, Analytical Lexicon; Romer, "Another Incarnation of the Phoenix," 231.

25 We do not encounter this in other evangelists. Matthew and Luke are followed by a passage in which Jesus expels the sellers and merchants from the temple, and Mark continues with the story of a withered fig tree. 
and resurrection. ${ }^{26} \mathrm{He}$ tries to show that the Evangelist John was not just making a random choice, but was concerned with the actual symbolism of the resurrection - whether to point to the resurrected Lazarus with whom Jesus dined or to the palm branches which had their symbolic meaning in Judaism (during the celebration of Sukkot as a symbol of joy and thanksgiving). Thus, Jesus entered Jerusalem in triumph, with the crowd greeting him with words and waving palm branches that symbolized victory, the triumph of the king and his very messianic promises (John 12:13). The palm tree is thus a familiar Jewish symbol of victory, and therefore stands out as a symbol of victorious immortality in the Jewish catacombs in Rome. This explains why later Christian art depicts the palm branch in the hands of martyrs. The Christian meaning of the palm leaf signifies victory and joy. ${ }^{27}$ This symbolism is narratively associated with the victory of Jesus, and the revival of Lazarus (John 11:1-5) is a sign of the promised resurrection. In his Gospel, in the context of Lazarus ,revival, John further describes (John 11:25) Jesus' answer to Martha: "I am the resurrection and the life ... Jesus, the Son of God, through faith in Him, gives a person life that will never be extinguished, a gift of participation (partaking) in the life of God Himself (John 6:50-51; $8: 51 ; 5: 24-25)$. These texts are characterized by the negation of death in the Semitic sense of man's destruction in the darkness of Sheol. John gives prominence to the hope of resurrection that is realized in Christ. Through his coming, the prospect of eternal life has been opened before man. ${ }^{28}$ Both of these stories, the solemn entry of Jesus into Jerusalem and the resurrection of Lazarus, thus become a sign of resurrection and eternal life.

The story of the resurrection of Lazarus in John presents Jesus not only as the one who performs miracles, but as the one who is the resurrection itself (John 11:25-26; 6:40.54). Christology has direct implications for ecclesiology. "Resurrection" was a familiar theme in ancient texts, but most often it was only the apparent resurrection from apparent death, and John seems to have been responding primarily to the spread of the Christian story (rumor). This story is crucial to John's plot development. ${ }^{29}$ Keener opines that, "In John's scheme it is the climactic and most miraculous episode in the series of signs he presents. Whereas in Mark Jesus dies because he challenges the municipal aristocracy of Jerusalem by his prophetic act in the temple, in John Jesus dies most immediately because he has given life to a disciple (11:14-16.50-52; 12:9-11). “30 That Jesus dies to give life, even on a symbolic level, is the essential soteriological message of John (3:16-17).

26 Romer, "Another Incarnation of the Phoenix," 223-229.

27 Romer, "Another Incarnation of the Phoenix," 231-232.

28 S. Mędala, Ewangelia wedtug świętego Jana. Rozdziaty 1-12 (Nowy Komentarz Biblijny 4/1; Częstochowa: Edycja Świętego Pawła 2010) 803-805, 816. Ježiš, ktorý sa zjavuje ako život v Jn znamená večný život. Večný život vo význame kvalitatívne rozdielnej existencii od tej dočasnej.

29 Throughout the text, the crucial point is that Jesus is the one who gave Lazarus (physical) life as a sign of his power to give eternal life on this earth (realized eschatology) and also the promise that he will rise from the dead on the last day (final eschatology). See R.E. Brown, The Gospel according to John, I-XII (Garden City, NY: Doubleday 1966) 436-437; C.S. Keener, The Gospel of John. A commentary (Grand Rapids, MI: Baker Academic 2012) 282-283. 
John's Gospel cannot be understood without early Judaism, since its chronology is constructed according to the Jerusalem festivals, conducts a polemic with the Jewish elite, and employs various Jewish symbols. The significant influence of this gospel is manifested mainly after its adoption among Gnostics and other writers, at the end of the $2^{\text {nd }}$ century AD. In the following century, this manifested itself mainly in catacomb art - when frescoes are created as the encounter of Jesus with the Samaritan woman at the well (in Kalixt's catacombs in Rome) and a little later, a fresco of the resurrection of Lazarus (the first in the Catacombs of Priscilla) is depicted. At the end of the $4^{\text {th }}$ century AD. they brought the Constitutiones Apostolorum, a paraphrase of the Gospel of John in a fragment on the resurrection of Lazarus as an indicator of a general resurrection. This also had an impact on the fact that frescoes of Lazarus' resurrection appear from the $2^{\text {nd }}$ century in the catacombs throughout their history up to 63 times,$^{31}$ more than any other New Testament scene. The catacomb inscriptions show that at the beginning of the $3^{\text {rd }}$ century AD, the Christian community in Rome spoke Greek, although the emphasis has shifted to Latin. As we pointed out at the beginning, F.E. Romer analyzes the connection between the palm twigs, the phoenix, and the story of Lazarus. They all come from and point to the same symbolic element of resurrection and victory (even over death), and therefore we identify with the idea that all of them intentionally refers to their symbolism. The palm trees, like evergreen cedars, symbolize eternal life, but the idea of eternal life refers only indirectly to the resurrection, which is the central tenet of Jesus' teaching and the pathway to eternal life. In this literary context, the phoinix symbolize rebirth and immortality, which are the central ideas of the Lazarus story, and it is in this context that they are related to the phoenix bird, which explicitly in Greek, Roman, and Egyptian mythology is the embodiment of rebirth and renewal. ${ }^{32}$

In this literary context, phoinikes symbolize rebirth and immortality, which are the main motive in Lazarus" story and these characteristics are also embodied by the phoenix bird in Greek, Roman and Egyptian mythology.

Compared to John's synoptics, the context is significantly different. The palm branches (12:13; only in John) suggest a ceremonial entrance for a military triumph or royal acclamation (1 Macc 13:51; 2 Macc 10:7; 14:4). John may have added palm branches simply to heighten the symbolism of the messianic exclamation; palm branches are meant to symbolize victory or triumphal entry $(\operatorname{Rev} 7: 9)$. John greets the beginning of the scene with palm branches and the exclamation from Ps 118:25. Against this background, the crowd appears to have a political subtext and welcomes Jesus as the national deliverer. The confirmation is 12:13 that the crowd came to meet him as the king of Israel. The gesture of greetings with palm branches evokes the symbol of Maccabean nationalism (also the palm tree was on the coins of the Second Rebellion (AD 132-135). The ecclamation "Hosanna!"

31 For more information, see the article, where there is a table of catacomb paintings with their classification into each century and the number of individual frescoes. Kardis -Tlučková, "Historicko-religionistická analýza," $14-38$.

32 Romer, "Another Incarnation of the Phoenix," 230-231, 242. 
is associated in Jewish tradition with the greeting of kings (2 Sam 14:4; 2 Kgs 6:26), in conjunction with the palm branches, suggests that the crowds hoped for him as a king or national deliverer. ${ }^{33}$

The fact that there is a connection between the palm tree and the phoenix - phoinix and phoenix, is again recorded by Pliny the Elder in his books Natural History. ${ }^{34}$ These are not just similar-sounding words, but also their properties. ${ }^{35}$ In this work describes that the Phoenician palm /a palm tree/ is found in Chora and is the only one of its kind with which is associated with a remarkable story that it dies and then comes to life again on its own. Pliny writes that it shares this peculiarity together with the phoenix, which is why, according to him, this palm tree was also named. At the time of publication and writing of his book, this tree had large, hard and prickly fruits, and its aroma was different from other fruits because it resembled the smell of pork. ${ }^{36}$ The etymology of word similarity is present only in Greek, because latin Palma $=$ Gr. Phoinix. ${ }^{37}$ Egyptian words ${ }^{38}$ for phoenix and palm have a common etymological origin. For the word phoenix, the Egyptian name is benu (rise) and benert for a palm tree. These words have the so-called superficial similarity. In both words, benben pyramidion - a mythical hill on which the deity settled. Benben is also the top stone of the pyramid. This is one of the reasons why benu-phoenix was often depicted on top of the benben pyramidion. ${ }^{39}$

The Greeks and Romans considered the palm tree to be the tree of Apollo. According to Aristotle, Aula Gelicia and Plutarch, the palm tree was a symbol of immense strength, resilience and victory. Therefore, it was customary to give the winners of various competitions as a sign of victory palm wreaths. This custom was originally adopted by the Romans from the Greeks. ${ }^{40}$ Therefore, the equivalent of Lat. the word "palm" is a sign of personal victory or winner, or general victory.

\section{Mentions of Phoenix in Roman and Greek Culture}

The phoenix is mentioned in a Greek epic from the $8^{\text {th }}-7^{\text {th }}$ century BC from Hesiod, where the longevity of the phoenix is discussed: „....while the phoenix survives nine ravens, but we Nymphs....we survive ten phoenixes... ${ }^{41}$ According to inaccurate and unconfirmed data,

\footnotetext{
33 Keener, The Gospel of John, 868-869; Brown, The Gospel according to John, 461-462.

34 Pliny, Natural History XIII, IX, 39-42 (Pliny, Natural History. IV. Libri XII-XVI. With an English Translation in ten Volumes [trans. H. Rackham] [London: Harvard University Press -Heinemann 1960] 121-123).

35 Romer, "Another Incarnation of the Phoenix," 232.

36 Pliny, Natural History XIII, IX 42 (Pliny, Natural History, IV, 122).

37 Romer, "Another Incarnation of the Phoenix," 232-233.

38 We discuss this more in the description of the phoenix in Egyptian mythology, see paragraphs below.

39 Romer, "Another Incarnation of the Phoenix," 232.

40 Compare Royt - Šedinová, Slovnik symbolì, 103-104.

41 Hesiodos, Precepts of Chiron Fragment 3 [from Plutarch de orac. Defectu. 2.415C], https://www.theoi.com /Thaumasios/Phoinix.html [access: 27.8.2020].
} 
the phoenix should live up to 972 years, not 500 years. In any case, although we cannot determine the exact age of the phoenix from this, we have the evidence that this bird was already known in the $8^{\text {th }}$ century BC.

The first detailed description of the phoenix in Greek can be found in Herodotus' The Histories, from the $5^{\text {th }}$ century BC. Herodotus was in Egypt and visited Heliopolis, where he heard about the phoenix and whom he saw on papyrus and carved in stones or hieroglyphs. It is more than certain that this description left canonical traces in later authors. He mentions the phoenix as a sacred bird, which he never saw except in pictures, and that he does not find the Egyptian descriptions of this bird very convincing. He further writes that this bird arrives in Egypt, Heliopolis, when its father dies. "If the picture really shows its size and appearance, its plumage is partly gold and partly red. It has the shape and size of an eagle. What is being said about this bird is unbelievable to me. He flies from Arabia to the temple of Helios (sun) and transports his father wrapped in myrrh and buries him in the temple of Helios. First he forms as heavy an egg of myrrh as he can carry, then he tries to pick it up and when he tries it, he carves an egg and puts his father in it. With another myrrh, he tapes a hole in the egg in which he put his father. The egg weighs the same even though my father lies in it and passes it to the Temple of the Sun in Egypt (Egypt).4 ${ }^{* 2}$

Publius Papinius Statius, poet from the $1^{\text {st }}$ century BC, wrote his work Silvae, in which he mentions a phoenix: "a long-lived phoenix is preparing for his death on the altar in Egypt. ${ }^{\text {‘3 }}$

Five centuries after Herodotus, a description of this mythical animal is provided by Pliny the Elder in Natural History. Book X. He writes that it is said among the people that Ethiopia and India have a phoenix. An exceptionally colorful and indescribable bird from Arabia, which has a famous color, is the only one in the world and it is very difficult to see it. According to stories, he is as big as an eagle and has shiny gold around his neck ${ }^{44}$ and the rest of his body is purple. He has a blue tail with a pink feather, he has tufted tufts on his throat and his head is decorated with a comb. Manilius was the first to talk about him, saying that there had never been anyone who had seen one of his feedings, that he was dedicated to the sun god in Arabia, he had lived for 540 years. As he ages, he builds a nest with twigs of wild cinnamon and incense, filling his place with a scent in which he lies down until he dies. Subsequently, his bones and body flesh form a kind of worm that grows and looks like a chicken. Here the funeral rites for the former bird begin to apply and the whole nest is transferred to the city of the Sun near Panchai, where it is placed on the altar. $\mathrm{He}$ further states that the period of the Great Year coincides with the life of this bird - then the same data about the seasons and the stars are returned. It begins around noon on the day the sign enters the sign of the Aries. The year of that period was 215, which was stated in the consulate by Publius Licinius and Gnaeus Cornelius. Cornelius Valerianus states that

\footnotetext{
42 Herodotus, Histories 2.73, https://www.theoi.com/Thaumasios/Phoinix.html [access: 27.8.2020].

43 Statius, Silvae 3.2.101. Available on: https://www.theoi.com/Thaumasios/Phoinix.html [access: 27.8.2020].

44 The color is meant - that is, the gold color on the neck.
} 
the phoenix flew from Egypt to the consulates of Quintus Plautius and Sextus Papinius. According to the writings, he was transported to Rome during emperor Claudius' reign. The phoenix was also to appear in the Comitium. ${ }^{45}$ This fact has been confirmed by records, although no one doubts that this phoenix was made-up. ${ }^{46}$

In the Acta Diurna ${ }^{47}$ it was recorded that the phoenix flew to Egypt in $36 \mathrm{AD}$ and in $47 \mathrm{AD}$ was brought to Rome and exhibited at the earlier mentioned Comitium. ${ }^{48}$

The egyptian benu bird seems to have been a prototype of the phoenix myth. The differences between the phoenix by Herodotus or other classical authors and the benu bird from ancient Egyptian sources are so serious that many scientists wondered why they were related. They consider that all the evidence and documents submitted to Herodotus in Egypt could have confused him. The bird he saw in the pictures didn't have to be a phoenix, but it could have been an Egyptian vulture or Hor as a falcon. The mention of incense adds authenticity, as it was highly valued in Egyptian temple rituals. Nor does anyone know the position of the informants who gave this information to Herodotus in the priestly hierarchy. They could have belonged to the highest stratum of the priesthood and thus have come to know the whole Heliopolian theology well, or they could have belonged to novices who had just begun to master it. It is also about the skills of translators. The main common feature of the phoenix and the ben bird is that both are related to the Temple of the Sun in Heliopolis. ${ }^{49}$

Further mentions are found in Tacitus. Tacitus mentions the phoenix in the work The Annals 6. 28. ${ }^{50} \mathrm{He}$ writes that in $34 \mathrm{AD}$ under the consulate of Paullus Fabius Persicus and Lucius Vitellius, after many years, a phoenix came to Egypt, about which many identical but also controversial things were said. The creature is dedicated to the sun, and the artists who depicted its appearance agree that its appearance and colorful color are different from other birds. However, they differ in the number of years. The most acknowledged period is 500 years, with some claiming that 1461 years ${ }^{51}$ will pass in the meantime

45 Comitium - an open space in ancient Rome for public meetings that had religious and prophetic significance. Place of political and judicial activity Rome, place of assembly (author's note).

46 Pliny, Natural History X (Pliny, Natural History. III. Libri VIII-XI. With an English Translation in ten Volumes [trans. H. Rackham] [London: Harvard University Press - Heinemann 1967] 292-295).

47 Also known as Acta Populi or Acta Publica - short news, announcements and information that have been carved in stone or metal and displayed in public places. Something like the then form of today's newspaper (author's note).

48 Romer, "Another Incarnation of the Phoenix," 233.

49 G. Hart, Egyptské mýty (Praha: KMa 2006) 16-17.

50 Romer, "Another Incarnation of the Phoenix," 233.

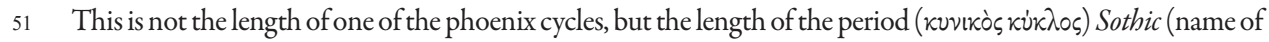
Sirius - Dog Star - in the ancient Egyptians) and Canicular (rise of the Dog Star or the star itself), at the end of which an error occurred from the difference between 365 days and the sunny year with 365 1/4 days. This period is associated with the beginning of each cycle, when the rise of the Dog Star, which occurred on the first day of Thoth - the day when the year opened. Such a cycle is also mentioned by the Roman writer Censorinus, who was to end in $139 \mathrm{AD}$ (for more information see: Tacitus, Annals. Books 4-6, 11-12 [trans. J. Jackson] [LCL 312; Cambridge, MA: Harvard University Press 1937] https://penelope.uchicago.edu/Thayer/E/Roman/ Texts/Tacitus/Annals/6B* .html [access: 27.8.2020]). According to some sources, August $29^{\text {th }}$ is the first day 
and that earlier birds flew to the city of Heliopolis (ancient Egypt), accompanied by other birds, during the reigns of Sesodius, Amadis a Ptolemy III Euergetes (the third king of the Macedonian family). However, less than 250 years have passed between Ptolemy III Euergetes (ruled in 247-222 BC) a Tiberius (ruled in 14-37 AD), and that is why some think that this phoenix was false, did not come from Arabia, and that he did not do what was written at the time. After completing a certain number of years, when his death is approaching, he begins to build a nest in his homeland and pours his fertile force into it, from which the young hatch. While the cub is growing up, his first task is to bury his father. It takes off with a load of myrrh and tries to go for a long journey. As soon as he manages to do so, he is supposed to take on his father's corpse, take it to the altar of the Sun and burn it there. Tacitus adds that it is uncertain and exaggerated by fables, but he does not doubt that the phoenix was seen in Egypt in that time..$^{52}$

The Annals were published shortly after Clement of Rome ( $1^{\text {st }}$ century AD) wrote a Letter to the Church of Corinth. Although Tacitus wrote in Latin not in Greek, the use and meaning of the phoenix was accepted by the imperial audience (pagans) as a powerful symbol of immortality and rebirth. An important feature of the bird is that after a long time (variously recorded as the years $257,500,540,1000,1461$, etc...) it dies and reincarnates itself from the ashes, and although this method of reincarnation is not explained in all ancient period descriptions, it was the most famous element of his life..$^{53}$

The period of Roman emperor Hadrian (117-138 AD) is also worth mentioning. The phoenix shows on Hadrian's coins ${ }^{54}$ during his reign the special interest the emperor had in the phoenix and in the heliopolitical cult. The analysis of the presence of the phoenix symbol on the Handrian's coins and scales offers several possibilities to clarify the religious and ideological system. The analysis of the presence of the phoenix symbol on the Handrian's coins and vase, ${ }^{55}$ offers several possibilities to clarify the religious and ideological system. This system is built into the Hadrian's environment, which does not seem to lack an intercultural relationship, a heterogeneous origin of the population and a connection with the pharaonic world. The Roman Hadrian coins, intended for their distribution, aim to convey the themes of Egyptian origin, the connection with Egypt, and with special emphasis on the regeneration and rebirth of the monarch and the individual in the universe, as well as in the case of the Pharaonic tradition. We also find in them the symbolism for

of the month of Thoth. This time was associated with the annual floods of the Nile, on which the fertility of the soil depended. (for more information see: J.J. Mark, “Thoth," Ancient History Encyclopedia, https://www. ancient.eu/Thoth/ [access: 27.8.2020]).

52 Cornelius Tacitus, Annales 6.28 (Letopisy [Praha: Svoboda 1975] 248-249).

53 Romer, "Another Incarnation of the Phoenix," 233-234.

54 The phoenix also appears on coins and medals with other emperors, such as the coins of Constantine II. Augusta with the inscription AETERNITAS. AVG. TEMP.REPARATIO [eternity of Augustus, happy renewal of time]. Some sources state that it is on the coins of Constantine II. See more Charbonneau-Lassay, The Bestiary of Christ, 448 .

55 Known as: Large bell-shaped crater alebo Egyptianizing crater from hadrian's Villa $\backslash$ is located in the Museum of History in Rome, the so-called Capitoline Museums. 
the occurrence of cyclic time, astral references and Hadrian's attention to astronomy, which was also reflected in other monuments. ${ }^{56}$

The work, in which there is another mention of the phoenix, comes from Claudius Aelianus, in his work De Natura Animalium (the $2^{\text {nd }}$ century AD). For example, he writes about the phoenix: "the phoenix knows how to count five hundred years without the help of arithmetic, because he is a student of all kinds, so he does not need fingers or anything else to help him understand numbers ..." 57

Another author is Lucius Flavius Philostratus with the work Life of Apollonius of Tyana, which was written in the years 217-238 AD. The work says: "The phoenix is a bird that visits Egypt every five hundred years, but the rest of the time it flies in India, and it is unique in that it emits sunlight and shines with gold. In terms of size and appearance, it is like an eagle and sits on a nest at the springs of the Nile..." 58

The famous Roman poet Publius Ovidius Naso also writes about the phoenix, and mentions him in his most famous epic composition Metamorphoses, which talks about the transformation of people into mythical animals or plants and things. ${ }^{59}$ The Slovak version, the text is translated as follows:

Now these I named derive their origin

from other living forms. There is one bird

which reproduces and renews itself:

the Assyrians gave this bird his name-the Phoenix.

He does not live either on grain or herbs,

but only on small drops of frankincense

and juices of amomum. When this bird

completes a full five centuries of life

straightway with talons and with shining beak

he builds a nest among palm branches, where

they join to form the palm tree's waving top.

As soon as he has strewn in this new nest

the cassia bark and ears of sweet spikenard,

and some bruised cinnamon with yellow myrrh,

he lies down on it and refuses life

among those dreamful odors.-And they say

that from the body of the dying bird

56 G.C. Vittozzi, "Emperor Hadrian and Egypt. Remarks on The Mythical and Religious perspectives," Arys 16 (2018) 267-288, https://www.researchgate.net/publication/335775928_Emperor_Hadrian_and_Egypt_ Remarks_on_the_mythical_and_religious_perspectives_El_emperador_Adriano_y_Egipto_Observaciones_sobre_las_perspectivas_miticas_y_religiosas [access: 9.9.2020].

57 Aelian, On Animals 6.58 [Greek Natural History], https://www.theoi.com/Thaumasios/Phoinix.html [access: 27.8.2020].

58 Philostratus, Life of Apollonius of Tyana 3.49 [Greek Biography], https://www.ancient.eu/Thoth/ [access: 27.8.2020].

59 Ovidius, Metamorphoses 15.385ff. [Roman epic], https://www.theoi.com/Thaumasios/Phoinix.html [access: 27.8.2020]. 
is reproduced a little Phoenix which is destined to live just as many years.

When time has given to him sufficient strength and he is able to sustain the weight, he lifts the nest up from the lofty tree and dutifully carries from that place his cradle and the parent's sepulchre. As soon as he has reached through yielding air the city of Hyperion, he will lay the burden just before the sacred doors within the temple of Hyperion.

There is a poem coming from the $4^{\text {th }}$ century AD about a phoenix by Claudius Claudianus (370-404) called Phoenix, he also mentioned phoenix in his unfinished epic De Rapti Proserpinae. ${ }^{60}$ A poem called Phoenix prosaically describes the life of a phoenix, the way he feeds and what he eats. He also deals with his appearance, about which he writes, that a mysterious fire flashes from his eyes and his head is enriched by a flaming halo and that his ridge glows with its own sunlight. It is also described that by self-destruction he will regain his lost youth and regain his life and be more exuberant than ever before. He will take his father to Egypt, accompanied by birds, where he will place him on the altar and is dedicated to the worship of the Sun. ${ }^{61}$

\section{Phoinix and Phoenix / Palm and phoenix in Jewish tradition}

In Jewish tradition, the word branch, or palm branch associated with the word "lulav" (pl. lulavim). This branch is associated with the feast of Sukkot - the feast of stalls, which are associated with the joy of liberation and the end of wandering in the desert. ${ }^{62}$ The use of the symbolism of palm leaves and green branches is nothing special for Jews. In 1 Macc 13:51 is written about palm branches, we can read from the text that palm leaves symbolize victory. The same is true of the purification of the temple from the pagan desecration described in 2 Macc 10:1-9, with the palm leaves described associated with the symbolism of joy and celebration. Romer describes that the lulav is a Jewish symbol of victory, used as a triumph of immortality in the Jewish catacombs in Rome and Venus. Among other things, the symbol of the palms was used to greet the victorious generals and kings, ${ }^{63}$

\footnotetext{
60 The abduction of Proserpine.

61 Claudius, The Phoenix, https://www.theoi.com/Thaumasios/Phoinix.html [access: 27.8.2020].

62 This holiday is connection with the harvesting of the autumn harvest (Lev 23:34-43). So the branches of the palm tree, the myrrh, the willows tied together, and their names were called for this feast. Etrongs (cedar fruits) were especially brought for this purpose. See more: F. Trstenský, Svet Novébo Zákona (Svit: Katolícke biblické dielo 2008) 94-95.

63 Romer, "Another Incarnation of the Phoenix," 229.
} 
where we can see a parallel with Jesus' triumphant entry into Jerusalem. In both Jewish and Christian traditions, the palm tree identifies with the tree of life. In the desert environment, palm trees are a sign of water and thus a symbol of life. The fact that the palm does not lose its green leaves symbolizes eternal life and in the psalms it is associated with deliverance from the enemy and the reward for righteousness (Ps 92:13). ${ }^{64}$

The palm is also a symbol of peace in the Old Testament. The palms were therefore depicted together with cherubs and flower wreaths. The palm tree had a similar symbolism in Babylon. ${ }^{65}$ In the Jewish Encyclopedia, the palm (Phoenix dactylifera) is described as an evergreen tree that grows in tropical climates and dry atmospheres. The name common to Aramaic, Ethiopian and Hebrew is tamar. The Arabic term tamr means mainly the fruit of a palm tree. Aramaic also use the term dikla and the feminine form dikleta. In ancient times, this tree was very widespread and abundant in Palestine, but now it is found only on Lake Gennesaret, near Jericho and around the Dead Sea. The palm tree is mentioned quite often in Jewish tradition. For example, in Joel 1:19 describes how joy in humans disappeared when palms and other trees dried up. In addition to the Feast of Tabernacles, palm trees were also used for sacrifices and worship in the temple (Lev 23:40, Neh 8:15). The palm tree was also used as a decoration in the Temple of Solomon (1 Kgs 6:29). Palms are also associated with the construction of the temple in th book of Ezekiel (Ezek 40:16-37). The abundance of palm trees is also evidenced by various names in the Old Testament. Jericho, for example, is called the city of palm trees (Judg 1:16;3:13). We also find connections with the word Tamar such as Asasontamara (2 Chr 20:2) or Baltamar (Judg 20:33), naming three women named Tamar (Gen 38:6, 2 Sam 13:1; 14:27). The Book of Judges mentions Deborah, who sat under a palm tree ${ }^{66}$ and judged Israel Judg 4:5.67

Phoenix plays a minor role in the Hebrew tradition. It also occurs in apocalyptic literature and intertestamental literature. However, F.E. Romer thinks that the bird in Ps 103:568 is probably not a phoenix. ${ }^{69}$ Consideration should be given to the translation of the Septuagint, where the word phoinix was interpreted or translated as phoenix, and confused in some modern translations, somewhere as "sand" (Job 29:18). ${ }^{70}$

64 A.R. Fausset, "Definition for Palmtree," Fausset's Bible Dictionary, https://www.bible-history.com/faussets/p/ palmtree/ [access: 29.06.2020].

65 Royt - Šedinová, Slovnik symbolì, 104.

66 That is also why the palm was called Deborah.

67 The fruit served as food and a drink was also distilled from it. The sheets were used as roofing, trunk and branches for construction purposes or for fuel. Some parts of the stems were used for weaving ropes. According to some Talmudic writers, a certain type of honey was also pressed from the flame. In: E.G. Hirsch - B.G. Levi, "Palm (Phoenix dactylifera)," Jewish Encyclopedia, http://www.jewishencyclopedia.com/articles/11873-palm [access: 13.8.2020].

68 "[...] he fills your years with good things, therefore your youth is renewed like an eagle [...]".

69 In the Dictionary of Biblical Culture, however, we encounter this explanation of Ps 103:5: "Although the Psalm speaks of an eagle, it clearly refers to the myth of the phoenix." (In: Slovnik biblické kultury [Praha: Ewa 1992] 62).

Romer, "Another Incarnation of the Phoenix," 232. 
However, it was believed that in Jewish folklore there was a bird named Hoyl. ${ }^{71}$ This bird was the only creature that refused to eat the forbidden fruit when Adam had it to be eaten by all the animals after tasting it with Eve. Hoyl, therefore, does not know death, and when he is about to die, he will be burned by divine fire in the nest. All that is left is an egg that hatches the new full-fledged Hoyl. ${ }^{72}$

\section{Phoinix / Palmin Christian Tradition}

In Christian catacombs, we encounter the palm tree as a commonly used Christian symbol. Probably most often we meet it on frescoes or tombstones. They appear either in the form of trees separating martyrs or as a branch in the hands of deceased martyrs. The Christian emblem of the palm tree is also a symbol of victory and joy ( $\operatorname{Rev} 7: 9)$. The palm tree becomes a common attribute of the martyrs and signifies their spiritual victory. As a symbol of victory, palm branches often decorated the graves of the first martyrs. Christian artists depicted a laurel crown and palm branch in connection with the Christian victory over sin and death. ${ }^{73}$

Likewise, Christ was likened to a palm tree, e.g. in Song 7:8-9, where the text is interpreted by biblical exegetes as a prediction of Christ's ascension to the cross. A palm cross appears on the ampoule from the treasure of the Monza temple, which clearly symbolizes the Christian significance of the cross as Christ's instrument of victory over death. In the apocryphal Pseudo-Matthew Gospel and the Golden Legend, ${ }^{74}$ there is a legend about a palm tree that refreshed the holy family as they fled to Egypt. In the story, angels bow their palm trees to the holy family to rest. ${ }^{75}$ According to the legend, Archangel Michael brought a palm branch from paradise to the Virgin Mary as a harbinger of impending death and at the same time spiritual triumph. This branch was then carried in the funeral procession of the Virgin Mary by St. John. ${ }^{76}$

\section{Phoenix in Christian Tradition}

The first mention of the phoenix the Christian tradition comes from the beginning of the $2^{\text {nd }}$ century. Specifically, he was mentioned by the already mentioned St. Clement of Rome

71 It is sometimes reffered to as Milcham or Chol; www.newworldencyclopedia.org/entry/Phoenix_(mythology) [access: 19.9.2020].

72 A.S. Mercatante - J.R. Dow, The Facts on File Encyclopedia of World Mythology and Legend, 3 ed. (New York: Fact On File 2009) 186.

73 For more information: "Palm Branch and Crown," A Guide to Christian Iconography. Images, Symbols, and Texts, https://www.christianiconography.info/palmCrown.html [access: 19.9.2020].

74 Jakub de Voragine, Legenda aurea (Praha: Vyšehrad 1984).

75 The theme of the frequent depiction of this motive in the late Middle Ages.

76 Royt - Šedinová, Slovník symboli̊, 103-104. 
in The first Epistle to the Corinthians, in chapters 25 and 26. Clement (about 88-97/101 $\mathrm{AD}$ ) was a bishop of Rome, whose St. Irenaeus named the fourth Roman bishop in the years of office 92-101 AD Although there are several uncertainties about the person of Clement and the authorship of the first Episte to the Corinthians (as the file itself is not signed and does not make any special reference to the author and authorship), this letter is called Clement's letter and the period of its origin is about $95-100 \mathrm{AD}$ and consists of 65 chapters. It is preserved in the Greek original and in the Syrian, Latin and Coptic translation. However, it is clear from the letter that it was written by a person who had very high recognition in Rome, as he expressed himself and intervened in the internal problems and conflicts of the church there. This work can also be understood as a church-political document, as it is known that there was ungodly strife and conflicts in the removal of priests in Corinth. ${ }^{77}$

Clement tells the story of a phoenix and does not doubt its symbolic meaning:

[...] a bird called a phoenix lives in the countries of the Arabian Peninsula and lives for 500 years. As he approaches death, he turns incense, myrrh, and other fragrant plants into a sanctuary into which, when his time comes, he enters and perishes. A worm is born from a crumbling body and feeds on the body of a dead animal. Then his wings will grow. And when he is strong, he shall lift up the sanctuary where the bones of his ancestor are. He takes these bones and flies with them from Arabia to Egypt to Heliopolis. During the day, everyone can see how he lays bones at the solar altar and flies away again [...]

In Chapter 26 he continues: "What does true faith allow? He even shows the validity of his promise with the help of a phoenix bird. After all, the Scriptures also point this out somewhere: you will raise me up and I will glorify you..." ${ }^{\text {"7 }}$ It is more than obvious that the description of the phoenix preserved by Herodotus was translated until the time of Clement of Rome and later. We can notice considerable to the same similarity of descriptions in individual authors.

Another document is Physiologus, which is one of the key texts of medieval teaching, and the predecessor of the book (or as one of its versions) Bestiarium (Physiologus is the oldest known Bestiarium, who the authorship is unknown). Physiologus was later supplemented by Isidore of Seville and St. Ambrose about passages from the Bible and the Septuagint, and therefore presents a Christian version of the accumulated knowledge of natural historians of the ancient world. The original Greek text Physiologus was compiled in Alexandria, between the $2^{\text {nd }}$ and $5^{\text {th }}$ centuries $A D$. This work was very popular, it was translated into Latin, Ethiopian, Arabic, Armenian, Syriac as well as other languages. ${ }^{79}$ It was an attempt

77 For more information Š. Mordel, Diela Apoštolských Otcov (Spišské Podhradie: Nadácia Kňazského seminára biskupa Jána Vojtǎšáka 2007) 18-56; english version of text: http://www.earlychristianwritings.com/ text/1clement-lightfoot.html [access: 29.06.2020].

78 Mordel, Diela Apoštolských Otcov, 36-37; http://www.earlychristianwritings.com/text/1clement-lightfoot. html [access: 29.06.2020].

79 This is how different versions of the Bestiarium were created - French, English, Latin American. Some of them are very different in content and description, which means that each transcript added or took something over, or threw it out, or even misinterpreted or misunderstood the idea (author's note). 
to redefine the natural world in the Christian sense. The material was drawn from Greek philosophers and their Latin followers, especially Aristotle, Pliny and smaller personalities such as C. Julius Solinus and Lucan. ${ }^{80}$ Among other things, these books as well as Beštiáre were enriched with beautiful paintings and drawings of these described mythical animals.

Physiologus (I, 7) places the origin of the phoenix in India and says that the phoenix is even more beautiful than the peacock, whose wings are ligated with greenery and gold. Its wings shine with hyacinths, emeralds and other precious stones, and it has a crown on its head. Every 500 years, the phoenix goes to the Lebanese cedars, where he fills his wings with scent. From there he will fly to the sunny city of Heliopolis. The priest to whom the arrival of the phoenix has been announced will make a high border of vinewood at the altar. When a bird flies, it will stand on the altar and be engulfed in fire, and it will burn itself. The next day, when the priest searches and inspects the altar, he finds a worm in the ashes. The next day, the wings will grow and it will become a young bird. On the third day, the priest discovers that the phoenix is as it was before. He solemnly greets the priest, takes off high, and flies to his old places. ${ }^{81}$

Another christian work that mentions the phoenix and its symbolic significance for Christians is in the Constitutiones Apostolorum. ${ }^{82}$ The file is dated in the years 375-380 AD and the author of the file is unknown. ${ }^{83}$ This work can also be found under other variations of names such as The Apostolic Constitutions or Constitutions of the Holy Apostles. The meaning and symbolism of the phoenix bird is mentioned specifically in V, 7 (Book 5. Concerning Martyrs and its Chapter 7 [Several demonstrations concering the resurrection, concerning the Sybil, and what the Stoics say concerning the bird called the Phoenix]). ${ }^{84}$ The author uses a similar argument to describe the phoenix bird to the Gentiles to better understand christian thought and the significance of the resurrection. In this book, the author explains the meaning and belief that Jesus' resurrection is the promise of our resurrection. He appeals to Christians to whom the pagans laugh and do not believe their Scripture, that he also informs the Sibyl about the resurrection (Orac. Sibyl. B. IV.) The author further writes that if the prophetess herself confesses the resurrection and does not deny the restoration of all things and does not distinguish the pious from the wicked, it is futile for pagans and other people to deny the Christian doctrine. Pagans also believe that there is a bird, the only one of its kind, without a partner and that provides rich evidence of resurrection. They call

80 R. Barber, Bestiary. Being an English Version of the Bodleian Library (Woodbridge: The Boydell Press 1999) 8-11.

81 Compare Royt - Šedinová, Slovnik symbolì, 175.

82 The Apostolic Constitutions - the collection of ecclesiastical laws by an unknown author written in Greek in the $4^{\text {th }}$ century. It consists of 8 books that deal with church discipline. Didaché is also included in one of the books.

83 Somewhere the author is mentioned under a pseudonym as Clement, bishop and inhabitant of Rome.

84 I. Chase, The Constitutions of the Holy Apostles, Including the Canons. Whiston's Version, Revised from the Greek, with a Prize Essay, at the Universityof Bonn upon Their Origin and Contents (Boston, MA: Damrell \& Moore 1848) 27. For more information: https://ldsfocuschrist2.files.wordpress.com/2012/03/apostolic-constitutions-william-whiston.pdf [access: 19.9.2020] or https://books.google.sk/books?id=xQ8aAAAAYAAJ\&printsec=frontcover\&hl=sk\&source $=\mathrm{gbs}$ ge_summary_r\&cad $=0 \# \mathrm{v}=$ onepage\&q\&f=false [access: 19.9.2020]. 
him a phoenix and claim that every 500 years he comes to Egypt for the so-called the altar of the sun, where it brings with it a large amount of cinnamon, cassia and balsamic wood. He turns to the east, prays to the sun, burns down from his own free will, and becomes dust. A worm emerges from the ash and transforms into a newborn phoenix. When he is able to fly, he heads to Arabia, which is beyond the borders of Egyptian countries. The author goes on to say that if the resurrection manifests itself in the form of an irrational bird for the Gentiles, why do they despise it so in vain and do not know how to accept the Christian faith. ${ }^{85}$

The phoenix primarily symbolized Christ and his resurrection. ${ }^{86}$ Such an interpretation is also admitted by other Christian writers, such as Tertullian (De carnis resurr. 13, CCSL 2, 936), Lactantius (De ave Phoenice, CSEL 27, 135) and Honorius of Autun (Spec. Eccl. 19, PL 172, 935). In Defensorium inviolatae virginitatis beatae Mariae, Franz von Retz symbolizes the phoenix of the Virgin Mary. Thomas of Cantimpré (De natura rerum) states that the phoenix, who has lived without a friend for 300-400 years, symbolizes a living soul with faith in the Holy Trinity and the four cardinal virtues. The size of the phoenix points to holy contemplation, the beauty of his head to the purity of the soul, and the tuft at his neck to the multiplied sense of contentment in prayer. The golden neck of the phoenix symbolizes the hope that comes from love, the purple feathers point to the suffering of Christ. $^{87}$

In Latin Bestiary ${ }^{88}$ from the $12^{\text {th }}$ century, the phoenix is also cited as evidence of resurrection. ${ }^{89}$ In this Bestiary, it is written that the phoenix is a bird from Arabia, which is called like that either because its color is like a dye from Fenicia or because it is unique in the world. He lives 500 years, and when he feels that he is aging, he begins to collect twigs from aromatic plants and creates a border on which he sits with outstretched wings turned into the rays of the sun and sets himself on fire. The next day, a new phoenix rises from the ashes. It goes on to say that: it is a symbol of our Lord Jesus Christ, who says:

I have the power to lay down my life and I have the power to take it back again. If the phoenix has the power to kill himself and bring him to life, why are you, a fool, angry at God's word, which is the true Son of God. Because our Savior descended from heaven and unfolded His wings, which were filled with the sweet fragrance of the Old and New Testaments. He sacrificed himself to God the Father on the cross of the altar and rose from the dead on the third day.

85 Chase, The Constitutions of the Holy Apostles, 27.

86 In the Renaissance, the phoenix became a symbol of permanence, hope and purity. For more info: Royt - Šedinová, Slovnik symboli.

87 Royt - Šedinová, Slovnik symbolì, 176-178.

88 See T.H. White, The Bestiary - A Book of Beast (New York: Capricorn Books 1960) 123-128.

89 The term 'bestiary', as genre, to refer to the medieval Latin texts that are based on the Physiologus, with additions from other classical, patristic, and medieval authors and that were written between the late tenth century and the early fourteenth. Mercatante - Dow, The Facts on File Encyclopedia, 785. 
This bird, in its example, teaches us to believe in the Resurrection, because the Resurrection is an event that is unparalleled and does not benefit from any reason. The phoenix produces all the symptoms of the resurrection; for the birds are here to teach man, not man to teach birds. Furthermore, Bestiary describes the cocoon and the cocoon of a phoenix in an egg made of myrrh as a cocoon of faith to be filled with the scent of good deeds. And as it is written, "I protected you with my wanderer."(Iza 49:2) At the end of your life, you should be clothed in this faith to enter your cocoon like a true phoenix and fill it with the scent of your martyrdom..$^{90}$

\section{Conclusion}

The presendted study deals analysis of the concept of phoenix symbolism. It was introduced its origin and etymology, from myths through Greek and Roman culture to its Christian transformation. We have analyzed with the meaning of the phoenix symbol in individual myths, and we have also incorporated it into Greek, Roman and Christian authors and their writings, which in some way describe or characterize the phoenix. We have found that by incorporating the symbol into individual cultures and quoting different writings, we can see a clear parallel and mutual influence, or the adoption of ideas about the phoenix. We also described the meaning and symbol of the phoenix in the Jewish and subsequently the Christian tradition and pointed out the basic motives and features of the phoenix, which were transformed in Christian thought. The oldest Christian fresco of the phoenix has been preserved in the Catacombs of Priscilla, which is very different from others early Christian depictions of the phoenix.

The main characteristic is its symbolic meaning, which resonates in almost all myths, religions and alchemies that it is reborn from its own ashes after voluntary burning and cremation. This unusual custom is variously understood and explained in different cultures. For dharmic religions, this means the victory of the soul over the body and the subsequent reincarnation. For others, it means destruction by fire, catharsis, or cleansing from death. For Christians, this is a reminder of the sacrifice made by Christ, the resurrection and eternal life, or life after death. ${ }^{91}$ His depiction in Christian art was under the auspices of the teachers of the faith, as a symbol of their teaching and as an image of Christ. All his depictions were in accordance with the ideas of rebirth, resurrection or rediscovery, victory and martyrdom. Perhaps, the most important legacy of the phoenix in Christian art is his reference to the image of Christ rising from the dead and triumphing over death.

\footnotetext{
90 Barber, Bestiary, 141-144, password: Phoenix.

91 A. Nozedar, Element Encyclopedia of Secret Signs and Symbols. The Ultimate A-Z Guide from Alchemy to the Zodiac (London: HarperElement 2008) 790-793.
} 


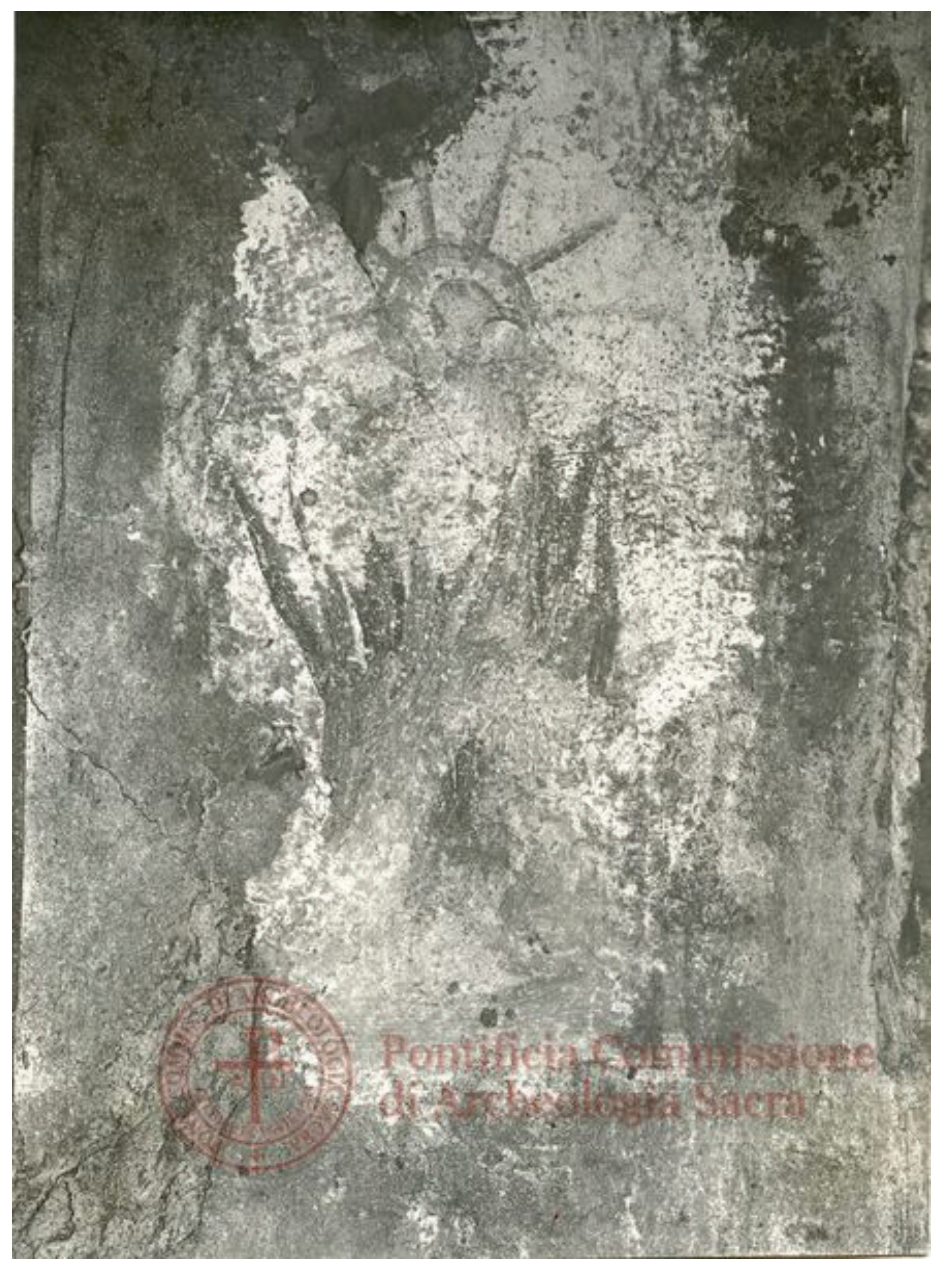

Figure 1: Phoenix dying in flames

Source: Archivio Pontificia Commissione Di Archeologia Sacra: Catacomba di Priscilla, Cappella Greca. STO - Pri, C, 14, https://media.xdams.org/dm_0/PCAS/PCASST02/low/foto/PRI/PRI_C/ PRI_C_014.jpg [access: 09.07.2020]. 


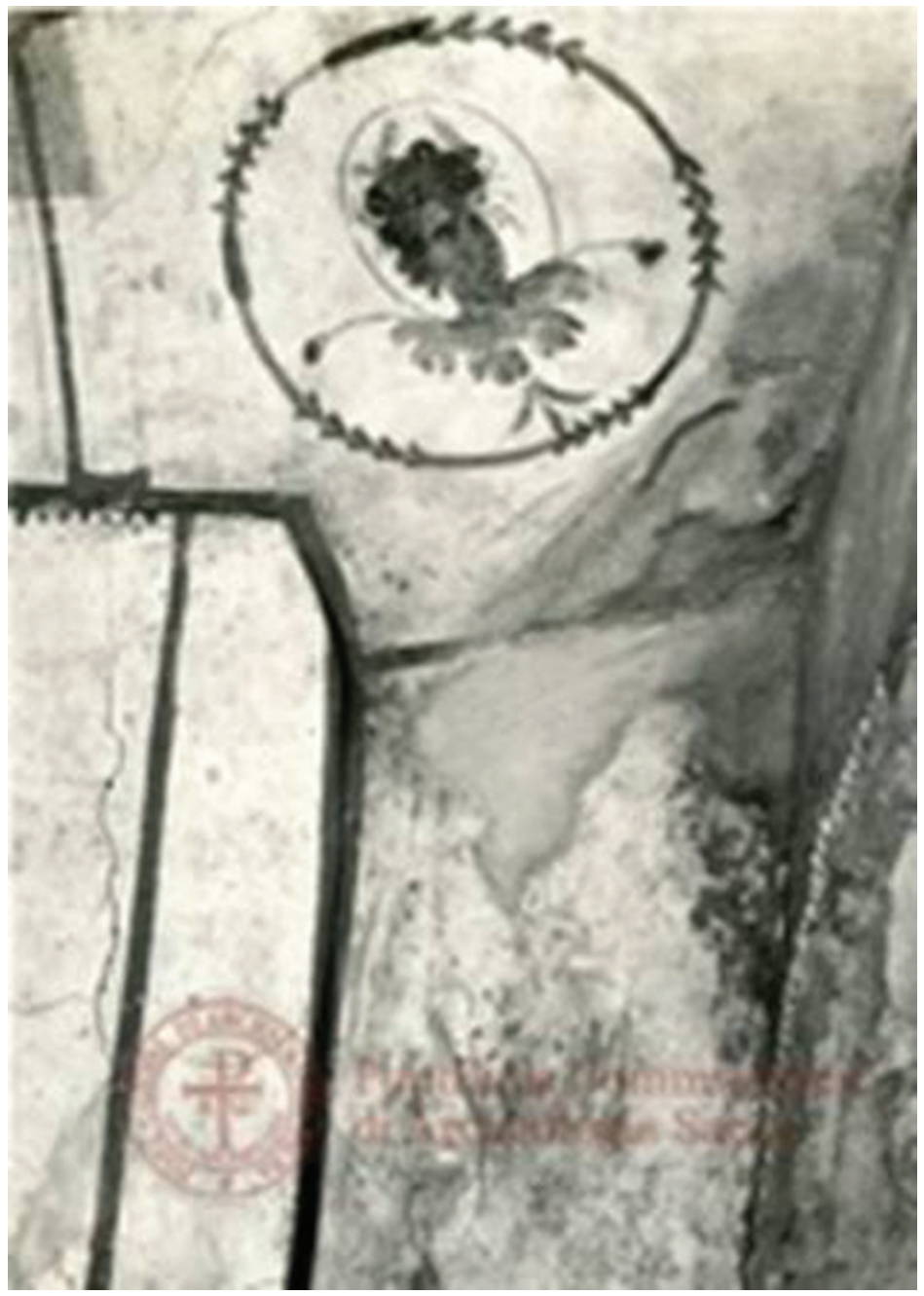

Figure 2: Phoenix on fire

Source: Archivio Pontificia Commissione Di Archeologia Sacra: Catacomba di Priscilla, Cappella Greca. STO - Pri, C, 17, https://media.xdams.org/dm_0/PCAS/PCASST02/low/foto/PRI/PRI_C/ PRI_C_017.jpg [access: 09.07.2020]. 


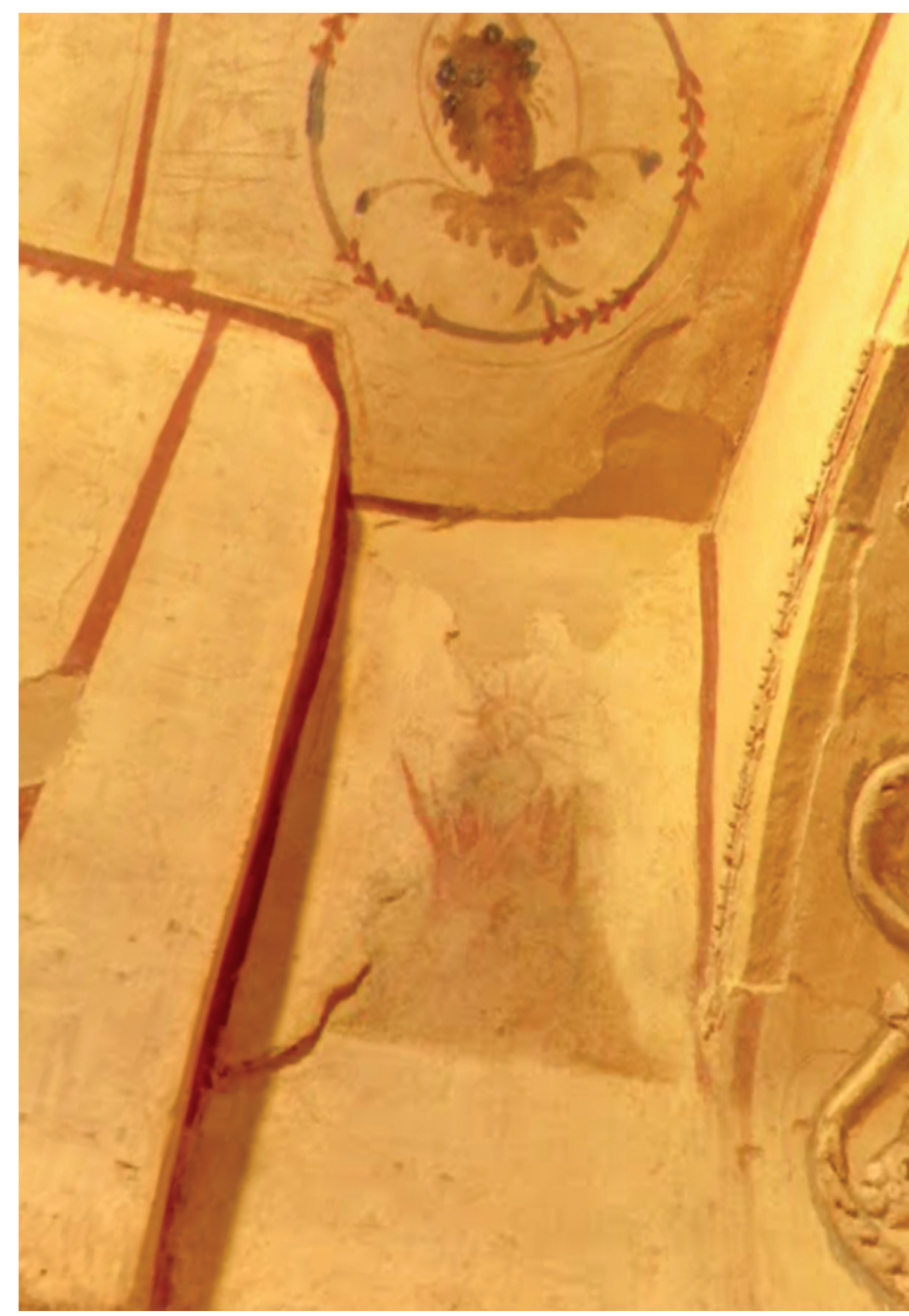

Figure 3: Restored fresco of the phoenix dying in flames

Source: Catacombs of Priscilla, Virtual Tour, Capella Graeca. https://www.google.com/maps/place/ Catacombs+of+Priscilla/@41.9293271,12.5090897,2a,75y,108.66h,116.7t/data=!3m6!1e1!3m4!1sY e7NvV1aflAAAAQJOCIaFQ!2e0!7i13312!8i6656!4m5!3m4!1s0x132f614730819a3f:0x6ac5a8c1e5 $4625 \mathrm{~b} ! 8 \mathrm{~m} 2 ! 3 \mathrm{~d} 41.9296856 ! 4 \mathrm{~d} 12.5086347$ [access: 09.07.2020]. 


\section{Bibliography}

Barber, R., Bestiary. Being an English Version of the Bodleian Library (Woodbridge: Boydell Press 1999).

Brown, R.E., The Gospel according to John, I-XII (Garden City, NY: Doubleday 1966).

Bunson, M., Encyclopedia Of Ancient Egypt (New York: Fact On File 2002).

Charbonneau-Lassay, L., The Bestiary of Christ (New York: Parabola Books 1991).

Chase, I., The Constitutions of the Holy Apostles, Including the Canons; Whiston's Version, Revised from the Greek, with a Prize Essay, at the Universityof Bonn upon Their Origin and Contents (Boston, MA: Damrell \& Moore 1848) https://ldsfocuschrist2.files.wordpress.com/2012/03/apostolic-constitutions-william-whiston.pdf or https://books.google.sk/books?id=xQ8aAAAAYAAJ\&printsec=frontcover\&hl=sk\&source=gbs_ge_ summary_r\&cad $=0 \# \mathrm{v}=$ onepage\&q\&f=false [access: 19.9.2020].

Fausset, A. R., "Definition for Palmtree," Fausset's Bible Dictionary, https://www.bible-history.com/faussets/p/ palmtree/ [access: 29.06.2020].

Flusser, D., Judaism and the Origins of Christianity (Jerusalem: Magnes - Hebrew University 1988).

Friberg, T. - Friberg, B. - Miller, N.F., Analytical Lexicon of the Greek New Testament (BibleWorks 10).

Giuliani, R. - Mazzei, B., The Catacombs of Priscilla (Vatican City: Pontifical Commission of Sacred Archaeology 2016).

Hart, G., Egyptské mýty (Praha: KMa 2006).

Hengel, M. - Schwemer, A.M., Jesus and Judaism (Waco, TX: Baylor University Press 2019).

Hirsch, E.G. - Levi, B.G., "Palm (Phoenix dactylifera)," Jewish Encyclopedia, http://www.jewishencyclopedia. com/articles/11873-palm [access: 13.8.2020].

Istituto Salesiano San Callisto, "The Symbols," The Christian Catacombs of Rome. The Catacombs of Saint Callixtus, https://www.catacombe.roma.it/en/simboli-cristiani.php [access: 15.07.2020].

Kardis, M. - Tlučková, D., “Historicko-religionistická analýza typológií pohanských symbolov v krestanských katakombách v Ríme [Historical-Religious Studies of Typologies of Pagan Symbols in Christian Catacombs in Rome]" Historia Ecclesiastica 10/2 (2019) 14-38, https://www.unipo.sk/public/media/34840/ historia_ecclesiastica_02_2019_WEB.pdf [access: 27.8.2020].

Katz, S.T., "The Rabbinic Response to Christianity," The Cambridge History of Judaism. The Late Roman-Rabbinic Period (ed. S.T. Katz) (Cambridge: Cambridge University Press 2006) IV, 259-298.

Keener, C.S., The Gospel of John. A Commentary (Grand Rapids, MI: Baker Academic 2012).

Mancinelli, F. - Fasola, U.M., Guide to the Catacombs of Rome (Trevi: Scala - Tecnostampa 2015).

Mark, J.J., "Thoth," Ancient History Encyclopedia, https://www.ancient.eu/Thoth/ [access: 27.8.2020].

Mercatante, A.S. - Dow, J.R., The Facts on File Encyclopedia of World Mythology and Legend, 3 ed. (New York: Fact On File 2009).

Mędala, S., Ewangelia wedtug świętego Jana. Rozdziaty 1-12 (Nowy Komentarz Biblijny 4/1; Częstochowa: Edycja Świętego Pawła 2010).

Mordel, Š., Diela Apoštolských Otcov (Spišské Podhradie: Nadácia Kňazského seminára biskupa Jána Vojtaššáka 2007).

Nozedar, A., Element Encyclopedia of Secret Signs and Symbols. The Ultimate A-Z Guide from Alchemy to the Zodiac (London: HarperElement 2008).

"Palm Branch and Crown," A Guide to Christian Iconography. Images, Symbols, and Texts, https://www.christianiconography.info/palmCrown.html [access: 19.9.2020].

Pinch, G., Handbook of Egyptian Mythology (Santa Barbara, CA: ABC-CLIO 2002). 
Pliny, Natural History. IV. Libri XII-XVI. With an English Translation in ten Volumes (trans. H. Rackham) (London: Harvard University Press - Heinemann 1960).

Pliny, Natural History. III. Libri VIII-XI. With an English Translation in ten Volumes (trans. H. Rackham) (London: Harvard University Press - Heinemann 1967).

Romer, F.E., "Another Incarnation of the Phoenix," Classica et Mediaevalia. Revue danoise de philologie et d\$bistoire 54 (2003) 223-253.

Rosik, M. “Zarzewie konfliktu między Kościołem a Synagogą (do 135 roku)," Jezus i chrześcijanie w źródtach rabinicznych (eds. K. Pilarczyk - A. Mrozek) (Estetyka i Krytyka 27; Kraków: Antykwa 2012) 69-103.

Royt, J. - Šedinová, H., Slovník symbolì. Kosmos, príroda a člověk v krestáanské ikonografii (Praha: Mladá Fronta 1998).

Sanders, J.T., Schismatics, Sectarians, Dissidents, Deviants. The First One Hundred Years of Jewish-Christian Relations (Valley Forge, PA: Trinity Press International 1993).

Slovnik biblické kultury (Praha: Ewa 1992).

Strassberg, R.E., A Chinese Bestiary. Strange Creatures from the Guideways through Mountains and Seas (London: University of California Press 2002).

Tacitus, Annals. Books 4-6, 11-12 (trans. J. Jackson) (Loeb Classical Library 312; Cambridge, MA: Harvard University Press 1937) https://penelope.uchicago.edu/Thayer/E/Roman/Texts/Tacitus/Annals/6B*. html [access: 27.8.2020].

Tacitus, Cornelius, Annales, trans. A. Minařík - A. Harmann: Letopisy (Praha: Svoboda 1975).

Trstenský, F., Svet Nového Zákona (Svit: Katolícke biblické dielo 2008).

U.X.L. Encyclopedia of World Mythology (Detroit, MI: UXL 2009) I-V.

Vittozzi, G.C., "Emperor Hadrian and Egypt. Remarks on The Mythical and Religious perspectives," Arys 16 (2018) 267-288.

White, T.H., The Bestiary - A Book of Beast (New York: Capricorn Books 1960).

Wróbel, M.S., "Motywy i formy żydowskich prześladowań pierwotnego Kościoła (I-II w. po Chr.)," The Biblical Annals 3 (2013) 421-438. 